TITLE:

\title{
Observation on the Dispersion State of Various Fillers in the Vulcanized Rubber by Electron Microscope
}

\section{$\operatorname{AUTHOR}(S):$}

Suito, Eiji; Arakawa, Masafumi

\section{CITATION:}

Suito, Eiji ...[et al]. Observation on the Dispersion State of Various Fillers in the Vulcanized Rubber by Electron Microscope. 京都大学化学研究所報告 1952, 29: 77-78

ISSUE DATE:

1952-06-30

URL:

http://hdl.handle.net/2433/74430

RIGHT: 
supply, stabilized by a vacuum tube circuit was constructed and was used to vary the focal length of the projecitve lens. The objective lens was operated to make the 1st reduced image and the projective lens to make the 2 nd reduced one of electron source, and by changing the focal length of the 2nd lens, the position of the apex of electron probe could be varied on the optical axis in the space between the fluorescent screen and just the front of the specimen. When apex of the probe existed between the screen and the specimen, its shadow image was bright but suffered a severe distortion. When the apex, however, was drawn back to the position between projective lens and specimen, a sharp but not so bright image without distortion could be obtained, and the order of magnification was increased from 50 to 500. By photographic enlargement we could obtain comparatively sharp positive print, whose order of the magnification was about 1,000-3,000. When the probe position. was drawn up till the screen, a diffraction pattern of the specimen could be obtained.

The shadow microscope is considered to be useful for the detection of the orientation of the lattice structure of the microcrystal, such as the gold sol particle “Trigon". (see, this Bull. 26 (1951) 78).

\section{Observation on the Dispersion State of Various Fillers in the Vulcanized Rubber by Electron Microscope}

Eiji Suito and Masafumi Arakawa

(Suito Laboratory)

In rubber industry, it is important to clarify the influence of those particle sizes, particle shapes and dispersion states of the reinforcer or the filler, upon the various properties, which when compounded with the natural or synthetic rubber. Hundreds electron micrographs on various inorganic fillers now being used mainly in this country were taken by the authors. Although there are numerous electron microscopic observations on the filler itself, scarcely any observation has yet been made on its dispersion state in rubber. We observed the dispersion state of some fillers and reinforcers when compounded with the vulcanized rubber, applying the combined methods of surface replica and merallic shadow casting. Those fillers as carbon black, basic magnesium carbonate, calcium carbonate and ultrafine calcinm carbonate, whose sizes and shapes had been measured by us with electron microscope, were compounded with rubar under the same condition, and they were vulcanized. The cross section of the rubber samples thus prapared, was observed with an electroa microscope, and thereby good electron micrographs, showing the dis- 
persion stata of the fillers in the vulcanized rubber, wese obtained. The dispersion of the various fillers in the rubber were quite good. It was made clear that the filler in the rubber was found to be dispersed as the primary particle, while usually the filler itself was often observed as the aggregates and clusters. Especially it was remarkable that the dispersion state of the ultra-fine powder of $400 \AA$ dia. in rubber was first clearly caught in a photograph.

Studies on the relationship b3tween the dispersion state of filler and the properties of rubber are now baing carried on in the expectation that some results might contribute to the theory of the filler in rubber.

\section{The Measurment of Specific Surface Area of Powders by Permeability Method \\ Masafumi Arakawa, Teru Arakawa and Eiji Suito \\ (Suito Laboratory)}

The fundamental conditions on the permeability methods were investigated. The Blaine's method and the Lea and Nurse method were used, and the calcium carbonates having different sizes and shepes were mainly used for samples.

Concerning the packing of the sample bed, it was confirmed that the specific surface area decreased linearly with the increase in the porosity function $(\varepsilon)$ of the same sample. The specific areas showed satisfactory agreement with the values by other methods at the minimum porosity function $\left(\varepsilon_{\mathrm{m}}\right)$. The influence of length and cross-sectional area of the sample bed on the measuring results were investigated and then their limits were found.

The results thus obtained are given in the following table.

\begin{tabular}{|c|c|c|c|c|c|c|}
\hline \multirow{3}{*}{ Sample } & \multirow{3}{*}{$\varepsilon_{m}$} & \multicolumn{5}{|c|}{ Average dia. $(\mu)$} \\
\hline & & \multicolumn{2}{|c|}{ Permeability } & \multirow{2}{*}{$\begin{array}{l}\text { Adsor- } \\
\text { ption }\end{array}$} & \multirow{2}{*}{$\begin{array}{l}\text { Micro- } \\
\text { scope }\end{array}$} & \multirow{2}{*}{$\begin{array}{l}\text { Sedimen } \\
\text { tation }\end{array}$} \\
\hline & & Blaine & $\begin{array}{l}\text { Lea- } \\
\text { Nurse }\end{array}$ & & & \\
\hline $\begin{array}{cc}\mathrm{CaCO} 3 & \mathrm{C} \\
\prime \prime & \mathrm{I} \\
\| & 6 \\
\prime \prime & \mathrm{U} \\
\prime \prime & \mathbf{9} \\
/ / & \mathbf{H}\end{array}$ & $\begin{array}{l}0.675 \\
0.797 \\
0.703 \\
0.573 \\
0.616 \\
0.472\end{array}$ & $\begin{array}{r}0.7 \\
1.6 \\
2.0 \\
3.4 \\
4.5 \\
12.0\end{array}$ & $\begin{array}{l}0.3 \\
1.6 \\
1.8 \\
3.4 \\
2.4 \\
7\end{array}$ & $\begin{array}{l}0.04 \\
1.8 \\
1.8 \\
- \\
3.2 \\
-\end{array}$ & $\begin{array}{c}0.04^{*} \\
1.8 \\
2.0 \\
3.5 \\
4.0 \\
11.0\end{array}$ & $\begin{array}{r}- \\
1.7 \\
2.5 \\
3.5 \\
4.0 \\
11.0\end{array}$ \\
\hline $\mathrm{ZnO}$ & 0.729 & - & 0.355 & 0.04 & 0.8 & 0.6 \\
\hline $\begin{array}{c}\text { Cement } \\
1 /\end{array}$ & $\begin{array}{l}0.381 \\
0.488\end{array}$ & $\begin{array}{l}7.9 \\
4.7\end{array}$ & $\begin{array}{r}10.0 \\
5.0\end{array}$ & - & - & $\begin{array}{l}9.9 \\
9.0\end{array}$ \\
\hline $\begin{array}{l}\text { Poly vinyl } 1 \\
\text { chloride } 2\end{array}$ & $\begin{array}{l}0.750 \\
0.672\end{array}$ & - & $\begin{array}{l}2.9 \\
4.3\end{array}$ & $\overline{-}$ & $\begin{array}{l}5.0 \\
40\end{array}$ & - \\
\hline
\end{tabular}

* Electron microscope. 